Catatan Penelitian

\title{
Scavenging Activity dan Intensitas Warna dari Ubi Kayu dengan Penambahan D-glukosa dan D-sorbosa
}

Scavenging activity and Color Intensity of Cassava with the addition of D-glucose and $D$-sorbose

Cleopatra Hendria, Anang Mohamad Legowo, Ahmad Ni'matullah Al-Baarri*

Program Studi Teknologi Pangan, Fakultas Peternakan dan Pertanian, Universitas Diponegoro, Semarang

*Korespondensi dengan penulis (albari@undip.ac.id)

Artikel ini dikirim pada tanggal 15 Mei 2016 dan dinyatakan diterima tanggal 01 Juli 2016. Artikel ini juga dipublikasi secara online melalui www.jatp.ift.or.id. Hak cipta dilindungi undang-undang. Dilarang diperbanyak untuk tujuan komersial.

Diproduksi oleh Indonesian Food Technologists $®(02016$

\begin{abstract}
Abstrak
Penelitian ini bertujuan untuk menganalisis scavenging activity dan intensitas warna yang dihasilkan dari reaksi Maillard pada ubi kayu yang dipanaskan dengan suhu $65^{\circ} \mathrm{C}$ selama 24 jam dengan pencelupan ke dalam larutan $0-2 \% \mathrm{~b} / \mathrm{v}$. Penelitian ini dilakukan di Laboratorium Kimia dan Gizi Pangan Fakultas Peternakan dan Pertanian dan Laboratorium Terpadu Universitas Diponegoro pada bulan Juli 2015 - Januari 2016. Bahan yang digunakan adalah ubi kayu, D-glukosa, D-sorbosa, DPPH dan alat yang digunakan adalah Digital Colormeter dan spektrofotometer. Hasil penelitian menunjukkan bahwa penambahan konsentrasi gula berpengaruh nyata pada nilai $a^{*}$ dan $b^{*}$ ubi kayu, namun tidak berpengaruh nyata terhadap nilai scavenging activity. Kesimpulan dari penelitian ini adalah konsentrasi gula dapat memberikan efek pada produk akibat adanya reaksi Maillard.
\end{abstract}

Kata kunci : D-glukosa, D-sorbosa, reaksi Maillard, scavenging activity, ubi kayu

\begin{abstract}
This research was aimed to analyze scavenging activity and color intensity of the Maillard reaction in a heated cassava at $65^{\circ} \mathrm{C}$ for 24 hours. This research was conducted at the Laboratory of Food Chemistry and Nutrition, Faculty of Animal and Agricultural Sciences and Integrated Laboratory of Diponegoro University during September 2015 - January 2016. Cassava was dipped into D-glucose and D-sorbose at 0-2\% w/v then was heated at $65^{\circ} \mathrm{C}$. The materials were cassava, D-glucose, D-sorbose, DPPH. Digital Colormeter on mac and spectrophotometer were used as research equipment. The results showed that concentration of sugars significantly affected the change in value of $a^{*}$ and $b^{*}$ but did not significantly affected the scavenging activity. As conclusion, the concentration of sugars might change the color intensity to a Maillard reaction product.
\end{abstract}

Keywords : Cassava, D-glucose, D-sorbose, Maillard Reaction, Scavenging Activity

\section{Pendahuluan}

Ubi kayu (Manihot esculenta crantz) merupakan salah satu komoditas pertanian Indonesia yang ketersediaannya cukup melimpah. Ubi kayu di Indonesia termasuk makanan pokok ketiga setelah padi dan jagung. Tumbuhan ini memiliki kelebihan yaitu walaupun penanaman dilakukan di tanah yang kurang air, yield karbohidrat yang dihasilkan tetap tinggi dan memiliki ketahanan terhadap serangan hama (Uarotta et al, 2016). Salah satu teknik pengolahan ubi kayu adalah dengan panas. Teknik ini digunakan untuk mengurangi kadar air yang terdapat di dalam ubi kayu setelah panen. Namun, kebanyakan masyarakat belum memperhatikan penanganan dan status gizi dalam pengolahan ubi kayu. Oleh karena itu, perlu dilakukan optimasi pengolahan ubi kayu.

Pengolahan ubi kayu dengan pemanasan kering dapat mengakibatkan terjadinya reaksi Maillard. Reaksi Maillard dapat meningkatkan fenol dan aktivitas antioksidan pada ubi kayu. Maillard terjadi karena pemanasan pada suhu tinggi dan reaksi antara gula dan protein. Reaksi Maillard sering disebut reaksi pencoklatan non enzimatik, reaksi ini terjadi karena gugus asam amino, peptida, karbohidrat dan protein bereaksi pada suhu tinggi (Zeng et al, 2012). Selain itu reaksi Maillard dapat menimbulkan aktivitas antioksidan karena pada reaksi tersebut menghasilkan beberapa senyawa misalnya flavonoid atau senyawa fenol. Dengan adanya reaksi tersebut kandungan senyawa antioksidan dalam bahan pangan yang dibutuhkan oleh tubuh meningkat. Senyawa negatif dihasilkan apabila reaksi Maillard terjadi secara berlebihan. Reaksi Maillard yang berlebihan dapat memunculkan senyawa negatif misalnya akrilamid yang dapat menimbulkan efek kanker. Perlu dilakukan perlakuan khusus untuk mengontrol reaksi Maillard agar tidak terjadi reaksi Maillard lanjutan. Sedangkan pengaturan suhu dan waktu pemanasan serta penambahan gula pereduksi dalam jumlah tertentu dapat mengontrol reaksi Maillard sehingga proses pembetukan senyawa antioksidan dari hasil dapat dikontrol. (Catrein et al., 2008).

Gula D-sorbosa merupakan gula jenis ketoheksosa dengan rumus molekul $\mathrm{C}_{6} \mathrm{H}_{12} \mathrm{O}_{6}$ dan mempunyai spesifikasi satu gugus $\mathrm{OH}$ yang berada di sebelah kiri dan dua gugus $\mathrm{OH}$ yang berada di sebelah kanan. D-sorbosa merupakan gula rare sugar yang dihasilkan dari D-psikosa yang kemudian dikonversi menjadi D-tagatosa. Lalu dengan menggunakan enzim isomerase, D-tagatosa dapat dikonversi menjadi Dsorbosa. Gula D-sorbosa merupakan gula yang jarang diminati oleh peneliti karena mahal dan belum banyak yang mengetahui kegunaan $\mathrm{D}$-sorbosa dalam industri 
pangan, Namun ternyata menurut penelitian (Furuse et al., 1994) rare sugar diketahui dapat menurunkan gula dalam darah secara signifikan. Selain itu, penambahan rare sugar pada ubi kayu dapat meningkatkan radical scavenging acivity (Sun et al., 2006 ${ }^{\mathrm{a}}$ ). Seiring perkembangan teknologi, gula jenis baru yang disebut rare sugar telah dikembangkan. Rare sugar adalah monosakarida yang sangat jarang ditemukan di alam dan pemanfaatannya masih belum diketahui secara luas (Sun et al., 2006 ${ }^{\mathrm{b}}$ ).

\section{Materi}

Bahan yang digunakan dalam penelitian ini meliputi ubi kayu, $D$-sorbose, $D$-glucose, akuades, asam asetat (MERCK, Germany), alkohol (MKR Chemicals, Indonesia), Phosphate Buffer, DPPH (1,1Diphenyl-2-picrylhydrazyl), $\mathrm{Na}_{2} \mathrm{CO}_{3} \quad(7.5 \% \mathrm{~b} / \mathrm{v})$, dan asam galat.

Penelitian dilaksanakan di Laboratorium Kimia dan Gizi Pangan, Program Studi Teknologi Pangan, Fakultas Peternakan dan Pertanian dan Laboratorium Terpadu Universitas Diponegoro yang dilaksanakan mulai bulan Juli 2015 sampai dengan bulan Januari 2016. Analisa scavenging activity diukur dengan menggunakan alat Spektrofotometer dan analisa intensitas warna diukur dengan menggunakan alat Digital Colormeter yang terdapat pada Macintosh.

\section{Perlakuan ubi kayu dengan gula}

Gula yang digunakan adalah D-glukosa dan Dsorbosa, masing-masing ditimbang sebanyak $1 \mathrm{~g}$ dan 2 $\mathrm{g}$, kemudian dilarutkan dengan akuades hingga volume menjadi $100 \mathrm{ml}$ dan diaduk hingga larut sehingga menghasilkan konsentrasi $1 \%$ dan $2 \%(b / v)$. Kemudian ubi kayu yang telah dikupas kulit luarnya dipotong dengan ukuran $2,5 \times 3 \mathrm{~cm}$ dan masing-masing direndam pada larutan D-sorbosa dan D-glukosa selama 15 jam dengan berbagai konsentrasi, yaitu $0 \%, 1 \%$ dan $2 \%$. Selanjutnya ubi kayu dipanaskan menggunakan slowrate heater pada suhu $65^{\circ} \mathrm{C}$ selama 24 jam dan kelembaban udara dalam ruang pemanas tetap dijaga agar mencapai $60 \pm 2 \%$.

\section{Analisis scavenging activity}

Analisis scavenging activity pada penelitian ini menggunakan metode DPPH. Sampel ubi kayu dihaluskan dan ditimbang sebanyak $0,1 \mathrm{~g}$ ke dalam 10 $\mathrm{ml}$ akuades kemudian di vortex dan di sentrifugasi selama 10 menit pada kecepatan $6000 \mathrm{rpm}$ untuk diambil supernatannya sebanyak $0,5 \mathrm{ml}$ setelah itu ditambahkan $2 \mathrm{ml}$ larutan 0,125 mM DPPH dalam larutan metanol. Larutan kemudian dicampur dan dibiarkan pada suhu ruang dengan keadaan gelap selama 30 menit. Absorbansi larutan diukur menggunakan spektrofotometer dengan kuvet $1 \mathrm{ml}$ pada panjang gelombang $517 \mathrm{~nm}$. Kontrol dibuat dengan perlakuan yang sama dengan akuades sebagai pengganti sampel (Sun et al., 2006 ${ }^{\mathrm{b}}$ ). Presentase radical scavenging activity dihitung dengan rumus, yaitu absorbansi blangko dikurangi absorbansi sampel lalu dibagi dengan absorbansi blangko dikalikan 100\%.
Analisis Intensitas Warna

Intensitas warna diukur dengan metode CIELAB. Sampel ubi kayu diletakkan di bawah kamera pada kondisi gelap dan diberi sumber cahaya yang terkontrol, kemudian menggunakan software DigitalColormeter dapat diketahui nilai $a^{*}$ dan $b^{*}$. Pengambilan data dilakukan dengan memfokuskan titik pada tiga tempat yang sejajar. Komponen warna $a^{*}$ memberikan nilai 120 untuk warna kehijauan dan 120 untuk warna kemerahan, serta komponen warna $b^{*}$ memberikan nilai -120 untuk warna kebiruan dan 120 untuk warna kekuningan (Amien et al., 2010).

\section{Analisis Statistik}

Rancangan percobaan dalam penelitian ini adalah Rancangan Acak Lengkap (RAL) dengan pola tersarang yang terdiri dari dua faktor, yakni jenis gula sebagai faktor pertama, dan konsentrasi sebagai faktor kedua. Pengambilan data dilakukan dari tiga kali pengulangan dan dihitung standar deviasinya.

\section{Hasil dan Pembahasan \\ Scavenging activity}

Berdasarkan data scavening activity ubi kayu, didapat hasil yang tidak signifikan terhadap peningkatan konsentrasi gula pada kedua jenis gula yang digunakan. Walaupun demikian, Nampak pada data yang didapat, terpadat adanya peningkatan nilai dari 17,37 menjadi 20,17\% (terdapat kenaikan sebesar $16,12 \%)$ ketika D-glukosa digunakan sebagai media pencelupan. Hal ini sangat berbeda dengan data yang didapat pada $\mathrm{D}$-sorbosa yang peningkatannya hanya sebesar $2,38 \%$ (Tabel 1 ).

Tabel 1. Nilai Scavenging Activity (\%) pada Ubi Kayu dengan Perlakuan D-glukosa dan D-sorbosa pada 0-2\% (b/v)

\begin{tabular}{ccc}
\hline $\begin{array}{c}\text { Konsentrasi } \\
(\%)\end{array}$ & D-glukosa $^{\text {ns }}$ & D-sorbosa $^{\text {ns }}$ \\
\hline 0 & $17,37 \pm 1,72$ & $18,03 \pm 1,09$ \\
1 & $18,55 \pm 3,50$ & $19,21 \pm 0,55$ \\
2 & $20,17 \pm 1,85$ & $18,46 \pm 0,21$ \\
\hline
\end{tabular}

*ns superskrip pada kolom menunjukan tidak terdapat perbedaan nyata $(P>0,05)$

Tabel 2. Intensitas Warna pada Ubi Kayu dengan Perlakuan D-glukosa dan D-sorbosa pada Konsentrasi 0-2\% (b/v)

\begin{tabular}{cccc}
\hline Jenis & \% gula & Nilai $^{*}$ & Nilai $^{*}$ \\
\hline D-glukosa & 0 & $-9,70 \pm 0,10^{\mathrm{a}}$ & $12,10 \pm 1,06^{\mathrm{a}}$ \\
& 1 & $-9,39 \pm 0,16^{\mathrm{ab}}$ & $15,64 \pm 1,88^{\mathrm{b}}$ \\
& 2 & $-9,03 \pm 0,15^{\mathrm{b}}$ & $17,67 \pm 1,01^{\mathrm{b}}$ \\
\hline D-sorbose & 0 & $-9,03 \pm 0,18^{\mathrm{x}}$ & $11,33 \pm 0,50^{\mathrm{x}}$ \\
& 1 & $-9,02 \pm 0,25^{\mathrm{xy}}$ & $11,96 \pm 0,13^{\mathrm{y}}$ \\
& 2 & $-8,94 \pm 0,19^{\mathrm{y}}$ & $12,10 \pm 0,43^{\mathrm{y}}$ \\
\hline
\end{tabular}

Huruf superskrip berbeda pada kolom yang sama menunjukan perbedaan nyata $(P<0,05)$

Scavenging activity dipengaruhi oleh reaksi Maillard yang mendonorkan hidrogen terhadap radikal bebas, sehingga menjadi lebih stabil atau sebagai antioksidan (Zeng et al., 2012). Namun pada penelitian ini tidak nampak adanya peningkatan scavenging activity yang signifikan. Hal ini dimungkinkan karena kadar protein dalam ubi kayu dinilai sangat sedikit (yaitu 
$\pm 2 \%$ ) sehingga tidak mampu memunculkan reaksi maillard secara sempurna yang berakibat kurang diproduksinya senyawa-senyawa penghasil antioksidan atau senyawa-senyawa tersebut secara relatif kurang banyak diproduksi. Jika dilihat dari besarnya peningkatan aktivitas antioksidan, maka D-glukosa nampak lebih reaktif dibandingkan dengan D-sorbosa dalam menangkap substrat. Hal ini menunjukkan bahwa D-glukosa memiliki potensi kemampuan yang lebih besar untuk melakukan proses reaksi Maillard. Hal ini sesuai dengan pendapat Mundt and Wedzicha (2003) yang menyatakan bahwa D-glukosa mampu bereaksi lebih baik dengan asam amino dibandingkan dengan gula lain untuk membentuk produk reaksi Maillard yaitu melanoidin dibanding monosakarida lain.

\section{Intensitas Warna}

Berdasarkan penelitian yang telah dilakukan penambahan D-glukosa dan D-sorbosa dapat meningkatkan nilai $a^{*}$ masing-masing sebanyak 6,90 dan $1,00 \%$. Penambahan gula D-glukosa dan Dsorbosa dapat meningkatkan nilai $b^{*}$ masing-masing sebesar 46,03 dan 6,80\% (Tabel 2). Secara statistic, peningkatan kadar gula dapat secara nyata meningkatkan nilai $a^{*}$ dan $b^{*}$ yang berarti bahwa warna pada ubi kayu menjadi lebih gelap. Hal ini disebabkan oleh adanya reaksi Maillard yang menghasilkan warna coklat. Nilai $a^{*}$ dan $b^{*}$ yang meningkat akan menyebabkan warna yang semakin gelap (Segovia, 2016; Amien et al., 2010). Chen (2016) menyatakan bahwa penambahan gula yang semakin tinggi dapat mempercepat produksi komponen furfural yang efeknya adalah perubahan warna coklat sehingga dapat perubahan warna yang terjadi pada hasil penelitian ini dapat dikatakan bahwa senyawa furfural telah muncul walaupun kurang begitu dominan.

D-glukosa tampak lebih dapat memberikan efek terhadap perubahan nilai $a^{*}$ dan $b^{*}$ daripada D-sorbosa karena adanya pengaruh dari jenis gula aldoheksosa (D-glukosa) yang lebih reaktif dibandingkan dengan gula ketoheksosa (D-sorbosa) (Phisut dan Jiraporn, 2013).

\section{Kesimpulan}

Konsentrasi gula tidak memberikan efek nyata terhadap nilai scavenging activity akan tetapi sangat mempengaruhi peningkatan nilai $a^{*}$ dan nilai $b^{*}$. Dglukosa tampak lebih reaktif dibandingkan dengan $D$ sorbosa.

\section{Ucapan Terimakasih}

Penulis mengucapkan terimakasih kepada Professor Shigeru Hayakawa dan Professor Masahiro Ogawa dari Kagawa University yang telah memberikan bantuan gula-gula yang digunakan untuk melaksanakan penelitian ini.

\section{Daftar Pustaka}

Amien, A. S., M. Hariadi dan I. K. E. Purnama. 2010. Perancangan dan pengaplikasian in beetwen frame berbasis mean shift clustering dan interpolasi linier untuk video animasi. Prosiding Penelitian Bidang Studi TKT, Surabaya.

Catrein, Y. S. Surya dan T. Ertanto. 2008. Reaksi Maillard Pada Produk Pangan. Institut Pertanian Bogor, Bogor. (PKM Penulisan IImiah).

Furuse, M., C. Kimura, H. Takahashi and J. Okumura. 1994. Influence of dietary sorbose on diabetes in nonobose diabetic mice. Camp. Biochem. fhysiol. 108(1):123-127.

Mundt, S. and B. L. Wedzicha. 2003. A Kinetic Model for the Glucose-Fructose-Glycine Browning Reaction. J. Agric. Food Chem. 51:3651-3655.

Phisut, N. and B. Jiraporn. 2013. Characteristics and Antioxidant Activity of Maillad Reaction Products Derived from Chitosan-sugar Solution. International Food Research Journal 20(3): 10771085.

Segovia, P. G., A. M. Ramos, Fiszman and J. M. Monzo. 2016. Effects of processing conditions on the quality of vacuum fried cassava chips (Manihot esculenta Crantz). Food Science and technology. 69:515-521.

Sun, Y., S. Hayakawa, M. Chuamanochan, M. Fujimoto, A. Innun dan K. Izumori. 2006 ${ }^{\mathrm{a}}$. Antioxidant effects of Maillard reaction products obtained from ovalbumin and different d-aldohexoses. J. Biosci. Biotechnol.Biochem. 70(3): 598-605.

Sun, Y., S. Hayakawa, S. Puangmanee, and K. Izumori. $2006^{\mathrm{b}}$. Chemical properties and antioxidative activity of glycated $\alpha$-lactalbumin with a rare sugar, D-allose, by Maillard reaction. Food Chemistry. 95:509-517.

Uarotta, V. W., R. Moresco, E. C. Schmidt, Z. L. Bouzon, E. D. C. Nunes, E. D. O. Neubert, L. A. M. Peruch, M. Rocha and M. Maraschin. 2015. The role of ascorbate peroxidase, guaiacolperoxidase, and polysaccharides in cassava (Manihot esculenta Crantz) roots under postharvest physiological deterioration. Journal Food Chemistry 197:737-746.

Zeng, Y., X. Zhang, Y. Guan, and Y. Sun. 2012. Enzymatic hydrolysates from tuna backbone and the subsequent Maillard reaction with different ketohexoses. International Journal of Food Science and Technology. 47:1293-1301. 